\title{
STUDIES OF APPLICATION CONDITIONS OF IN-FLOOR CONVECTORS WITH NATURAL AIR CIRCULATION IN WATER HEATING SYSTEMS
}

\author{
Viktor Pukhkal \\ Saint Petersburg State University of Architecture and Civil Engineering, \\ Vtoraja Krasnoarmejskaja ul. 4, St. Petersburg, 190005, Russia. \\ pva1111@rambler.ru
}

\begin{abstract}
To prevent the intake of downward cold air flow from translucent structures into the room serving area, convectors with natural convection, embedded in floor construction, are used. A test bench was manufactured for studies of heating systems with in-floor heaters with natural convection; studies of convector heat flow with various options of heating element arrangement in the installation box was conducted: from the room side right against the box wall; from the side of glazing right against the box wall; arrangement of a heating element in the center of the box. The studies were carried out at various distances from glazing to the convector. Simulation of convector operation was performed with ANSYS Fluent 14.5. program. Application conditions of in-floor convectors with natural air circulation were determined.
\end{abstract}

Keywords: heating, in-floor convector, natural convection

\section{Introduction}

In-floor convectors are intended for water heating systems of residential, public and administrative buildings including childcare centers, cottages, and offices (Boriskina, 2012; Krupov V, Krupov D, 2010; Mayorov, 2014; Makhov, 2014; Composite author, 2012; Nauchno-tekhnicheskaya firma OOO «VITATERM», 2008; Babiak et al., 2013).

Convectors with natural air circulation (natural convection) are used to prevent cold air flow intake from glazing into the room serving area and creation of comfortable indoor micro-climate.

Convectors are mounted into floor constructions along windows and walls of heated rooms and connected to water heating systems. They can be installed, for example, in lobbies, winter gardens and other similar rooms in residential buildings. When installing an in-floor convector, a box with a heat-exchange unit is hidden in the floor construction by submersion into cement screed or apertures organized in false floors. Only the false front remains visible. The false front can be longitudinal or lateral. It is made of anodized or coated with polymeric paint aluminum, as well as stainless steel, brass, or fine wood.
Most of embedded convectors have a box that is made of galvanized or stainless steel. An aluminum-copper heat-exchange unit is used as a heating element most often, but completely copper heating elements are also applied (in rooms with high humidity).

Heat-exchange units are made both end (supply and return pipelines are brought from one side) and pass ones for convenience of installation. Convectors with one-side connection have the following advantage: when connected to the heating system with flexible connectors, they make it possible to extract the heat exchanger from the box without disconnection from the system, which is convenient during cleaning.

Three options of heating element arrangement in the casing (installation box) are used (Fig. 1):

- option 1 - heating element arrangement from the room side right against a box wall;

— option 2 - heating element arrangement from the side of glazing right against a box wall;

- option 3 - heating element arrangement in the center of the box.

The convector is located directly at glazing or at a distance of $80-350 \mathrm{~mm}$ from the wall (glazing). 

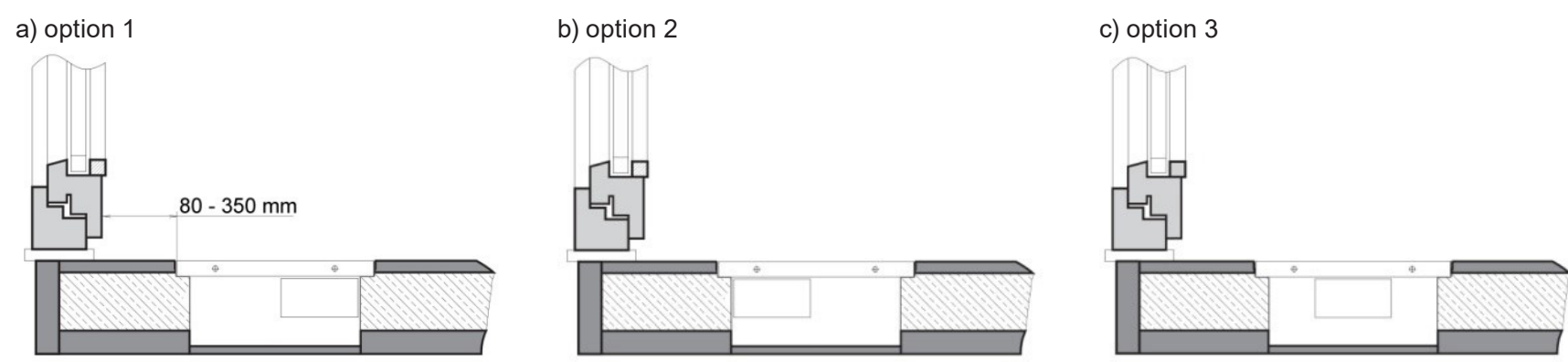

Fig. 1. Heating element arrangement options in the installation box

\section{Materials and Methods}

In order to study heat flow from the convector with various options of heating element arrangement in the installation box, a test bench was mounted in the "Heat and gas supply and ventilation" department laboratory of the SPbSUACE for thermal testing of heating units:

- a measuring heating circuit is located within the laboratory room; a closed (unventilated) test chamber with water cooled inner surfaces to provide preset temperature conditions required according to (GOST R 53583-2009) is not installed due to low heat intensity of the room and lack of air temperature gradient along the room height;

- measurement of heating unit heat flow is carried out by means of "water method" (GOST R 53583-2009): measurement of water flow rate through the heating unit and determination of enthalpy difference of water at the inlet and outlet; a heat meter of Kamstrup company with automatic recording of measured parameters is used as a measuring instrument; internal room air temperature is also recorded.

Scheme of the thermal bench is shown in Fig. 2. Water with the help of pump 2 circulates through electric boiler 1 and test heating unit 5 .
Experimental studies of KRKD 43.14.150 convector built in floor (OJSC "Izoterm", Russia) with an eight-tube heating element were carried out. The heating element is equipped with side sectional planks with the height of 32 $\mathrm{mm}$ from two sides. The main dimensions of the tested convector model: length $-1,500 \mathrm{~mm}$; convector depth $-430 \mathrm{~mm}$; convector height $-140 \mathrm{~mm}$. Pipes along the hear carrier flow are connected in each level in pairs according to the scheme from top to bottom for two levels.

The convector was placed at a distance of $0,100,190$ and $300 \mathrm{~mm}$ from the wall (glazing).

To account the actual operating conditions of the convector built in floor and for detailed study of distribution of velocity and temperature fields inside the room, convector operation was simulated with ANSYS Fluent 14.5 program.

The model considers a room with the following dimensions: width $-3 \mathrm{~m}$; depth $-6 \mathrm{~m}$; height $-3 \mathrm{~m}$. KRKP-1,058-128 convector of "Izoterm" company (Russia) was simulated. The convector is located at a distance of $100 \mathrm{~mm}$ from glazing.

In simulation, the following conditions were preset:

- temperatures of the internal surfaces (side walls, floor, ceiling) were preset to $+18{ }^{\circ} \mathrm{C}$;

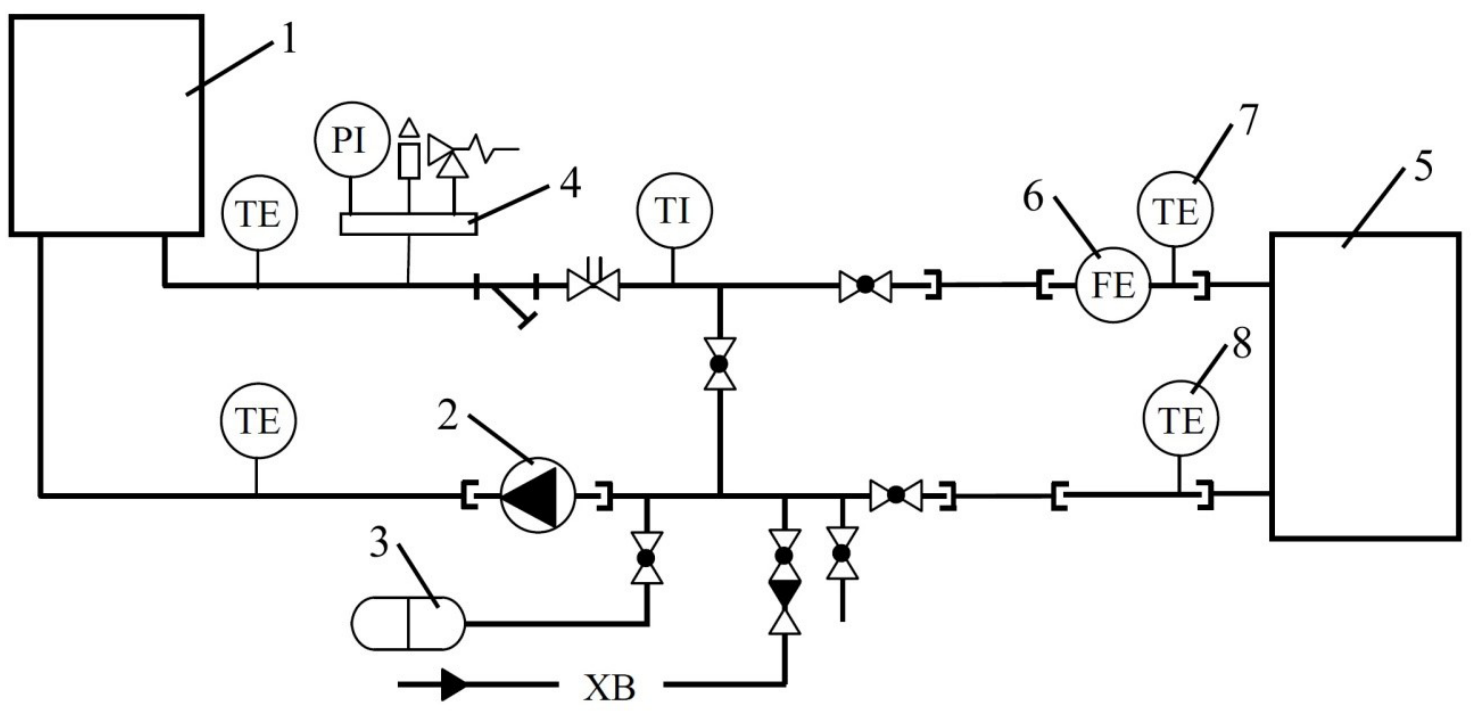

Fig. 2. Scheme of the thermal bench for heating unit testing

1 - adjustable electric boiler; 2 - pump; 3 - expansion tank; 4 - boiler safety group; 5 - test heater; 6 - heat meter flow rate sensor; 7 - heat carrier temperature sensor at the device inlet; 8 - heat carrier temperature sensor at the device outlet 


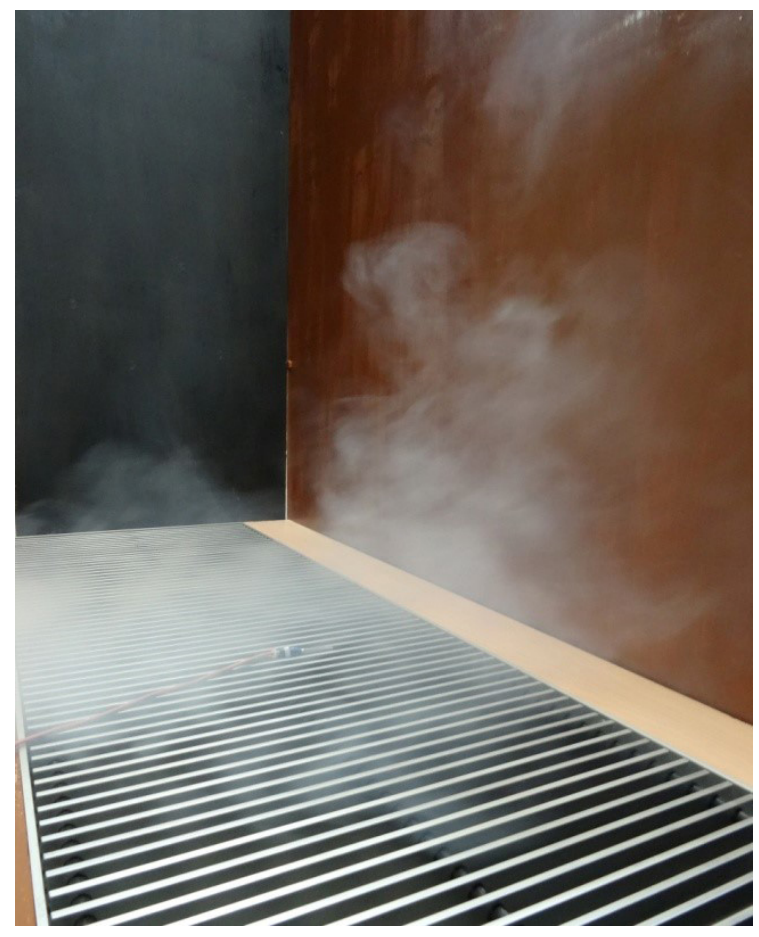

View inside the convector enclosure

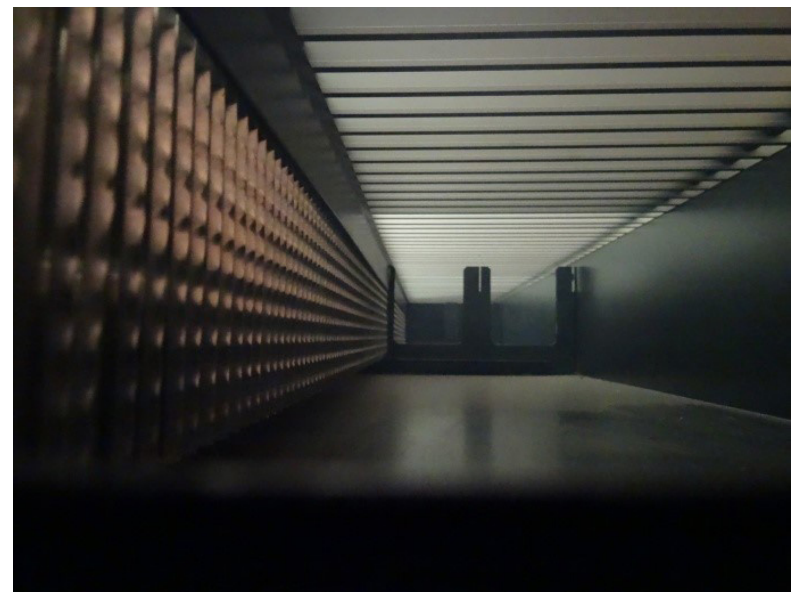

Fig. 3. Visualization of air flows (by smoke screening) at location of the heating element at a box wall from the room side (option 1); convector at a distance of $100 \mathrm{~mm}$ from the wall (glazing)

— outside air temperature - minus $24^{\circ} \mathrm{C}$;

- heat dissipation factor of the glazing outer surface $-23 \mathrm{~W} /(\mathrm{m} 2 \mathrm{~K})$;

- average thermal resistance of glazing - 0.685 $(\mathrm{m} 2 \mathrm{~K}) / \mathrm{W}$;

- uniform temperature over the entire surface of the convector was preset, which was equal to $44.5^{\circ} \mathrm{C}$.

\section{Results}

Upon thermal tests of the convector, it was established that change of the distance from the wall to the convector within the range from 100 to $200 \mathrm{~mm}$ slightly affected the convector heat flow. At increase of the distance from 100 up to $190 \mathrm{~mm}$ in option 3 (arrangement of the convector heating element in the center of the box), heat flow at the average temperature difference of $70^{\circ} \mathrm{C}$ decreased by $3 \%$ (from 1,365 W to $1,323 \mathrm{~W}$ ). Further increase of the distance from the wall to the convector up to $300 \mathrm{~mm}$ leads to decrease of heat flow by $7 \%$ (from $1,365 \mathrm{~W}$ to $1,266 \mathrm{~W}$ ).

When placing the convector at a distance of $100 \mathrm{~mm}$ from the wall, its maximum heat flow is provided upon location of the heating element at a box wall from the side of glazing $(1,441 \mathrm{~W})$. Heat flow decreases by $5 \%$ in case of heating element location in the center of the box, and in case of its location from the room side it decreases by $22 \%$.

Decrease in distance from 100 to $0 \mathrm{~mm}$ in option 1 (arrangement of the heating element from the room side right against a box wall) allows increasing heat flow by $3 \%$.

The executed visualization of air flows by smoke screening and thermal-imaging shooting show that in all cases spreading of a heated air jet from the convector onto the guard is observed. When spreading, the jet is pressed against the guard and dispersed. The jet, that spreads onto glazing, increases the glazing temperature (Fig. 3).

Reverse air flow, that comes through the grid to the heating element and leads to heat flow decrease, is observed at arrangement of the convector heating element from the room side right against the box wall. It should be noted that air temperature is measured at a point which is located on the central symmetry axis that is perpendicular to the chamber base at a distance of $0.75 \mathrm{~m}$ from floor (GOST R 53583-2009).

Qualitative picture of air flow motion at the convector heating element and glazing retains upon computer simulation as well (Fig. 4).
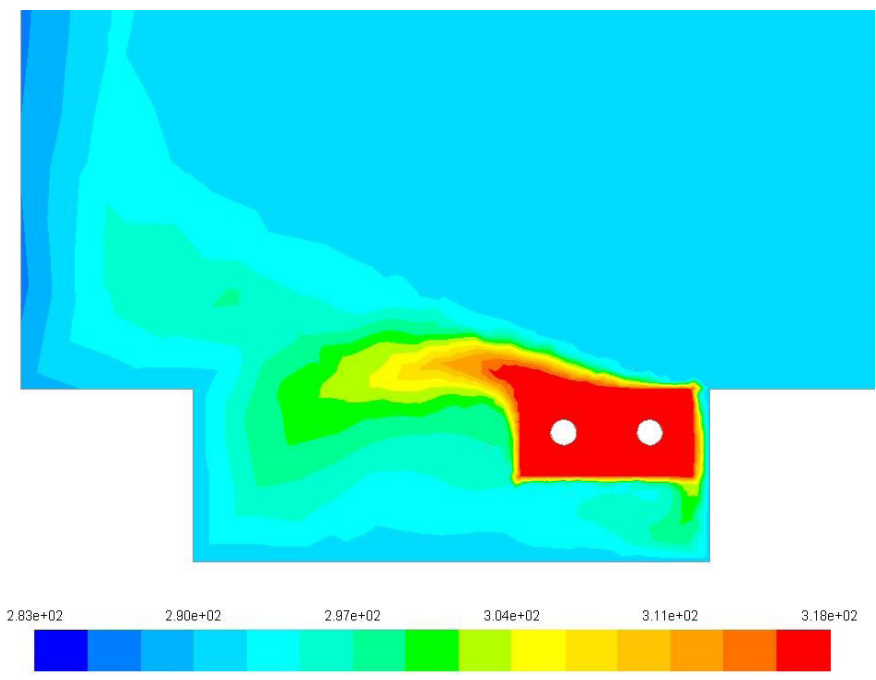

Fig. 4a. Temperature field in Option 1 of heating element arrangement in the installation box (convector is located at a distance of $100 \mathrm{~mm}$ from glazing) 


\section{Architecture and Engineering Volume 1 Issue 2}

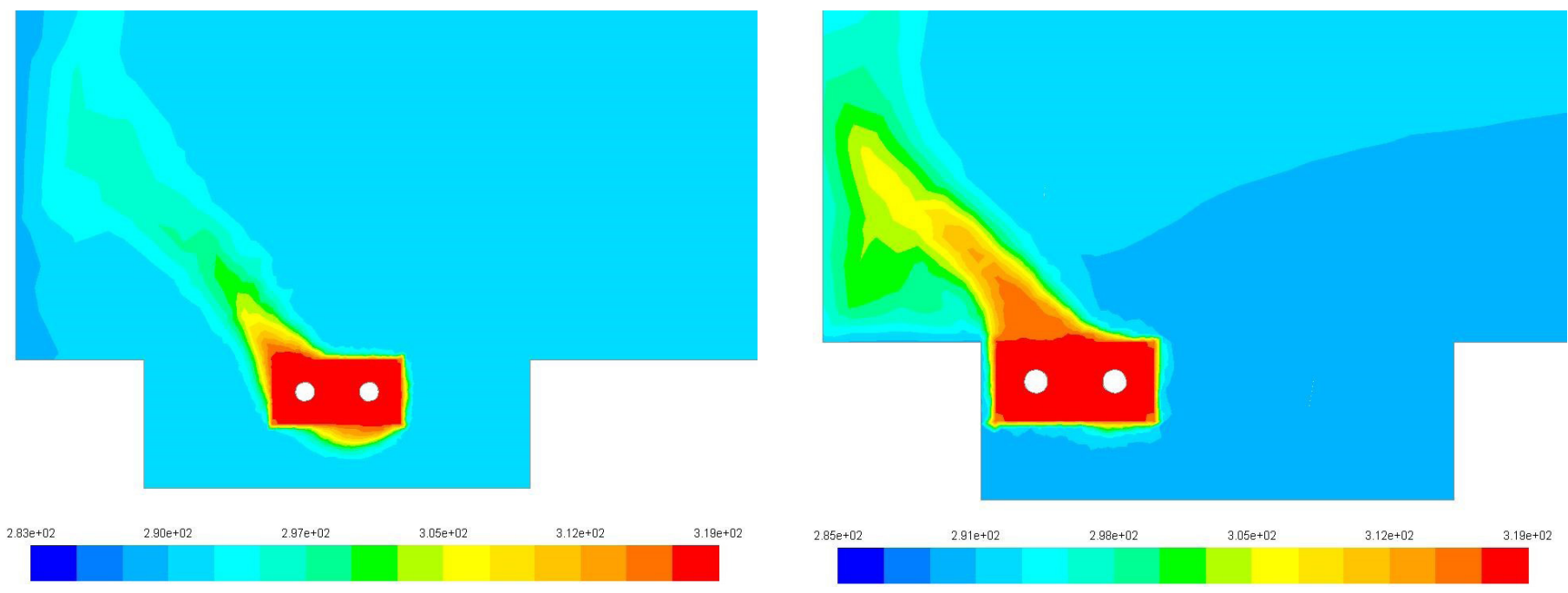

Fig. 4b. Temperature fields in Option 2 (left picture) and Option 3 (right picture) of heating element arrangement in the installation box (convector is located at a distance of $100 \mathrm{~mm}$ from glazing)

\section{Conclusions}

1. Convectors embedded in the floor plane create a convection jet, which spreads onto glazing. To eliminate the nonuniform heating of the glazing surface, the distance from the convector to the glazing surface should be at least $100 \mathrm{~mm}$.

2. Arrangement of the heating element of the in-floor convector with natural air circulation from the side of glaz- ing right against a box wall is recommended. The distance from glazing to the convector shall be within the range of 100 to $200 \mathrm{~mm}$.

3. Arrangement of the heating element of the in-floor convector with natural air circulation in the box center is permitted. The distance from glazing to the convector shall be within the range of 100 to $200 \mathrm{~mm}$.

\section{References}

Babiak J, Olesen Bjarne W, Petráš D (2013) Low Temperature Heating and High Temperature Cooling Embedded. Water Based Surface Heating and Cooling Systems. REHVA.

Boriskina I (2012) Zdaniya i sooruzheniya so svetoprozrachnymi fasadami i krovlyami. Teoreticheskie osnovy proektirovaniya svetoprozrachnykh konstruktsii [Buildings and structures with translucent facades and roofings. Theoretical basis of translucent structure's designing]. Inzhenerno-informatsionnyi Tsentr Okonnykh Sistem, Saint Petersburg, RF (in Russian).

Composite author (2012) Otopitel'nye pribory i poverkhnosti [Heating devices and surfaces]. Izdatel'skii Tsentr «Akva-Term», Moscow, RF (in Russian). ISBN: 978-5-905024-04-7

Federal'noe agentstvo po tekhnicheskomu regulirovaniyu i metrologii [Federal Agency on Technical Regulation and Metrology] (2009) GOST R 53583-2009: Pribory otopitel'nye. Metody ispytanii [Heating devices. Test methods]. Federal'noe agentstvo po tekhnicheskomu regulirovaniyu i metrologii, Moscow, Russian Federation.

Krupnov B, Krupnov D (2010) Otopitel'nye pribory, proizvodimye v Rossii i blizhnem zarubezh'e [Heating devices made in Russia and neighboring countries] Izdatel'stvo Assotsiatsii stroitel'nykh vuzov, Moscow. RF (in Russian).

Makhov L (2014) Otoplenie [Heating Izdatel'stvo Assotsiatsii stroitel'nykh vuzov, Moscow, RF (in Russian).

Mayorov V (2014) Peredacha teploty cherez okna [Heat transfer of through windows]. Izdatel'stvo ASV, Moscow, RF (in Russia).

Nauchno-tekhnicheskaya firma OOO «VITATERM» (2008) Rekomendatsii po primeneniyu konvektorov «Gol'fstrim» («lzotermTD»), vstraivaemykh v konstruktsiyu pola [Recommendations for use of "Gol'fstrim" ("Izoterm-TD") convectors which are built into the floor construction]. Second edition. NTF OOO «VITATERM», Moscow, Russian Federation. 